\title{
Plate Motions, Gondwana Dinosaurs, Noah's Arks, Beached Viking Funeral Ships, Ghost Ships, and Landspans
}

\author{
LOUIS L. JACOBS ${ }^{1}$, CHRISTOPHER STRGANAC ${ }^{1}$ and CHRISTOPHER SCOTESE ${ }^{2}$ \\ ${ }^{1}$ Roy M Huffington Department of Earth Sciences, Southern Methodist University, Dallas, TX, 75275, USA \\ ${ }^{2}$ Department of Geology, University of Texas at Arlington, Arlington, TX, 76019, USA
}

Manuscript received on November 10, 2009; accepted for publication on August 16, 2010

\begin{abstract}
Gondwana landmasses have served as large-scale biogeographic Noah's Arks and Beached Viking Funeral Ships, as defined by McKenna. The latitudinal trajectories of selected Gondwana dinosaur localities were traced through time in order to evaluate their movement through climate zones relative to those in which they originally formed. The dispersal of fauna during the breakup of Gondwana may have been facilitated by the presence of offshelf islands forming landspans (sensu Iturralde-Vinent and MacPhee) in the Equatorial Atlantic Gateway and elsewhere.
\end{abstract}

Key words: biogeography, dinosaur, Gondwana, latitude.

\section{INTRODUCTION}

In 1973 Malcolm C. McKenna published a paper titled, "Sweepstakes, Filters, Corridors, Noah's Arks, and Beached Viking Funeral Ships in Palaeogeography". His purpose was to reconcile the biogeographic principles elaborated by William Diller Matthew (e.g. Matthew 1915, 1939) and George Gaylord Simpson (e.g. Simpson 1940, 1943, 1946, 1947a, b, 1952, 1953), developed under a stable Earth perspective, with the then well accepted framework of plate tectonics. His fundamental conclusion was that the dispersalist principles elaborated by Matthew and Simpson were still relevant within certain mobilist caveats: sweepstakes routes are those in which odds of dispersal success are low, as in true rafting; filters are those which allowed the dispersal of some but not other species, usually due to the adaptations of the species involved and the environmental conditions of the route; and corridors are those in which movement was the most free of all.

McKenna (1973) defined a biogeographic Noah’s

Proceedings of the Third Gondwanan Dinosaur Symposium Correspondence to: Louis L. Jacobs

E-mail: jacobs@mail.smu.edu
Ark as a segment of continental crust with its biota, rifted and moved away from its continent of origin. He viewed Noah's Arks as permitting one-way dispersal of a balanced biota during which "the transported biota would evolve, and latitudinal components of motion would conceivably affect available ecospace via the effects of climatic change" (McKenna 1973, p. 302). In the same paper, McKenna also defined biogeographic Viking Funeral Ships as continental crust rifted away from one landmass and travelled to an adjacent landmass, carrying fossils from the first area, where the populations had lived, to the second area where a Funeral Ship beached and where the fossil biota had never lived. The formation of Noah's Arks and Viking Funeral Ships are features of divergent plate boundaries. Docked Noah's Arks and Beached Viking Funeral Ships are features of convergent plate boundaries and accreted terranes. Their effects on historical biogeography occur on the spatial and temporal scales at which lithospheric plates are created, subsumed, and move about.

McKenna (1983) added more mobilist biogeographic concepts derived from his plate tectonics perspective. One was "Escalator Counterflow", which en- 
visioned a rejuvenating volcanic pile at a spreading center without appreciable geographic displacement of the islands created, in which terrestrial organisms essentially moved "up the down escalator" through geologic time. Another was "Hopscotch on the Escalator" resulting from colonization of progressively younger islands along a hotspot trace, as exemplified by the Hawaiian Islands and Emperor Seamounts. The older islands move with the plate away from the hotspot, erode, and subside below sea level. The biota skips from the older eroding and subsiding island to newly formed islands at the intraplate hotspot. Some of the plants of Iceland, which have a fossil record going back to the Miocene origin of the islands (Grímsson et al. 2007), provide a possible example of Escalator Counterflow. The Galapagos biota (Christie et al. 1992, Grehan 2001) is possibly an example of Hopskotch on the Escalator. Another example might be living coelacanths on the slopes of underwater volcanoes near the Comoro Islands (Fricke and Hissman 1990). The volcanos formed much later than the clade. Green sea turtles that breed on islands of the Mid-Atlantic Ridge (Carr and Coleman 1974, Bowen et al. 1989) may also represent hopscotch. However, neither concept has seen much application to non-avian dinosaurs.

More recently, historical biogeography of islands was revitalized with the introduction of landspans, defined by Iturralde-Vinent and MacPhee (1999, p. 52) as "a subaerial connection (whether continuous or punctuated by short water gaps) between a continent and an off-shelf island (or island arc)". This stands opposed to land bridges, which Iturralde-Vinent and Macphee (1999, p. 52) restricted to mean "land linkages between continental regions". A significant difference between the two is the dispersal of organisms between lands on oceanic and continental crust in the former, and lands on continental crust only in the latter. Iturralde-Vinent and MacPhee (1999) applied the concept of the GAARlandia landspan, which is defined as a landmass comprising the conjoined Greater Antilles and Aves Ridge islands, and then examined dispersal mechanisms in the light of sea-level change, tectonic evolution, and vicariance of the Carribean fauna (Iturralde-Vinent and MacPhee 1999). The purpose of Iturralde-Vinent and MacPhee (1999) was to explain the biota of the Antilles; how- ever, if the concept of landspans is expanded to allow subaerial connection punctuated by short water gaps between off-shelf islands (i.e., those developed on oceanic crust) and two adjacent continents, then the concept of landspans becomes relevant when considering the dispersal of Gondwana dinosaurs, and elaborates the mobilist concepts presaged by McKenna.

We have two purposes in this paper. The first is to trace the latitudinal drift of selected Gondwana dinosaur localities (Fig. 1, Table I) through time from the Triassic (220 Ma, Carnian), when continents were united in Pangea, until the present day. This is useful for comparing where fossil localities were formed to where they are now in terms of the climate zones they traversed because, to repeat again McKenna's words, "latitudinal components of motion would conceivably affect available ecospace via the effects of climatic change". General Circulation Models (GCMs) consistently indicate high global temperatures and low latitudinal temperature gradients during the Mesozoic (Sellwood and Valdes 2006). Nevertheless, GCMs are tested by the rock and fossil records, so unless otherwise determined, the first order causes of climate zonation should have been applicable in the Mesozoic as they are now, modified by higher order climatic influences included in the models.

Non-avian dinosaur localities, Gondwana dinosaur localities in particular, are ideal for this sort of review because they reflect the breakup of Gondwana into its constituent components and their dispersal to their present positions on the globe. The breakup of Gondwana brought about first-order biogeographic change for all its component terrestrial biota. Africa, South America, Madagascar, India, Australia, and Antarctica were, in effect, very large-scale Noah's Arks. The tectonic drift of these arks through latitudinal climate zones was the first-order cause of environmental changes to which the biota living on the drifting Gondwana fragments was subjected. Each fragment of Gondwana moved through climatic zones at different rates and crossed climatic boundaries at times specific to the place.

Our second, more speculative purpose is to identify where and when landspans may have most greatly affected Gondwana dinosaur dispersal in the context of continental movements. The relationships of landmasses in close proximity to each other as they converge 
or diverge in tectonically active terranes deserve attention as biogeographic landspans because those settings create island arcs and hotspot traces, which by definition are off-shelf islands and therefore potential participants in landspans.

In addition to first-order influences on historical biogeography caused by plate motions, eustatic sea-level fluctuation (Haq et al. 1987, 1988) has a major influence on the distribution of organisms and the amelioration of climate. A major cause of global sea level fall is the sequestering of water in continental glaciers. Presumably this was not an important factor in the Cretaceous as that was a period of globally warm temperatures, a low pole-to-equator temperature gradient, and high sea level (Bice et al. 2003, 2006, Bice and Norris 2002, Jacobs et al. 2005). There is no convincing evidence of permanent polar ice caps during the Cretaceous Period. It has been proposed that large-scale sea level change and climate change are directly related to plate tectonic events (Scotese 2004, Müller et al. 2008), and thus are tied to the breakup of Gondwana. During times of continental dispersal and rapid sea-floor spreading, such as the Cretaceous Period, the volume of ocean basins decreases resulting in higher sea levels (Scotese 2004).

Atmospheric Hadley Cells, which affect regional climate, are caused by insolation striking the curved surface of the Earth, leading to warm moist air rising in the tropics and cool dry air descending between about 15 and 30 degrees latitude in both the northern and southern hemispheres. The rotation of the Earth imposed upon atmospheric cells leads to zonal wind patterns such as the Intertropical Convergence Zone, which marks the equatorial limit of Hadley Cells, and the dry trade winds characteristic of the arid zones at the poleward limits of the Hadley Cells. There is short-term latitudinal variation in the position of these boundaries and in the intensity of the cells due to the orientation of the Earth (Diaz and Bradley 2004, Sachs et al. 2009). Additional complexity is added to the pattern by the location, orientation, and geography of land, mountains, shallows, and oceans. However, over geologic time, at the scale considered here, the latitudinal limits of the Hadley Cells have remained relatively stable. This is based on evidence from the distribution of climate-sensitive sedimentary rocks (Scotese et al. 1999, Ziegler et al. 1981,
2003), from modeling (Sellwood and Valdes 2006, Haywood et al. 2000), and from specific examples (e.g., the Atacama Desert along the west coast of South America, Hartley et al. 2005) where deserts associated with the descending limbs of the Hadley Cells have remained apparently at the same latitude through time. The relative stability of Hadley Cells does not imply a stable climate. Rather, it provides predictability for the distribution of climatic zones.

\section{METHODS}

We traced the path over the globe of selected dinosaur localities (Fig. 1, Table I) using the Point-Tracker program published by the PALEOMAP Project (Scotese 2008), in which the present-day latitude and longitude coordinates of 51 localities are reconstructed back into their paleolatitudinal positions at progressively older $10 \mathrm{Ma}$ intervals back to $100 \mathrm{Ma}$, and in $20 \mathrm{Ma}$ intervals between $100 \mathrm{Ma}$ and $220 \mathrm{Ma}$. Latitude was plotted because climate changes with latitude, and latitude can be determined more accurately than longitude. We display these trajectories as simple plots with time on the $\mathrm{x}$-axis and with paleolatitude on the y-axis (Figs. 26). The sites were selected because together they help elucidate the history of specific regions, and individually they are illustrative of the general principles outlined by McKenna (1973). Each of these localities is only a single point on the continents being tracked, and does not represent the entire continent as a unit. Therefore, rotation of a single continental landmass can become obvious through the convergence or crossing of trajectories. Localities are plotted with reference to ocean basins because the oceans are formed through rifting and seafloor spreading and provide a natural focus for the discussion of movement of the bordering regions with their entombed fossils.

Scotese (2004) lists the following sources of data for the construction of paleogeographic maps: (i) linear magnetic anomalies of the sea floor; (ii) paleomagnetism, (iii) hotspot tracks and large igneous provinces, (iv) tectonic fabric of the ocean floor, (v) lithologic indicators of climate, and (vi) the geologic record of plate tectonic history. For the Cretaceous, the latitudinal error associated with the localities chosen for this study is less than $\pm 5^{\circ}$ (Bocharova and Scotese 1993). In ad- 
TABLE I

Dinosaur localities examined. Numbers as in Figure 1 and discussed in text. Data from Weishampel et al. 2004.

\begin{tabular}{|c|c|c|c|c|c|c|}
\hline$\#$ & Formation & Location & Taxa & Age & Lat & Lon \\
\hline 1 & Gres d'Assaouas & Départment d'Agadez, Niger & $\begin{array}{l}\text { therapod tracks } \\
\text { sauropod tracks }\end{array}$ & Late Jurassic-Hauterivian & 18 & -9 \\
\hline 2 & Argiles de I'Irhazer & Départment d'Agadez, Niger & $\begin{array}{l}\text { therapod tracks } \\
\text { euornithopod tracks }\end{array}$ & Late Jurassic-Hauterivian & 18 & -9 \\
\hline 3 & Tiouraren Formation & Départment d'Agadez, Niger & $\begin{array}{l}\text { Therapoda } \\
\text { Tetanurae } \\
\text { Afrovenator abakensis } \\
\end{array}$ & Hauterivian-Barremian & 18 & -9 \\
\hline 4 & Elhraz Formation & Départment d'Agadez, Niger & $\begin{array}{l}\text { Therapoda } \\
\text { Spinosauridae } \\
\text { Suchomimus tenerensis } \\
\text { Cristatusaurus lapparenti } \\
\text { ?Spinosauridae indet. } \\
\text { Tetanurae indet. } \\
\text { Therapoda indet. } \\
\text { Sauropoda } \\
\text { Diplodocoidea } \\
\text { Nigersaurus taqueti } \\
\text { undescribed titanosaurian } \\
\text { Sauropoda indet. } \\
\text { Ornithopoda } \\
\text { Iguantodontia } \\
\text { Valdosaurus nigeriensis } \\
\text { Ouranosaurus nigeriensis } \\
\text { Lurdosaurus arenatus }\end{array}$ & late Aptian & 18 & -9 \\
\hline 5 & "Continental intercalaire" & Départment d'Agadez, Niger & $\begin{array}{l}\text { Therapoda } \\
\text { Avetherapodia incertae sedis } \\
\text { Bahariasaurus ingens } \\
\text { Allosauroidea } \\
\text { Carcharodontosaurus saharicus } \\
\text { Therapoda indet. (= Inosaurus } \\
\text { tedreftensis, Elaphrosaurus } \\
\text { iguidiensis, E. gautieri) } \\
\text { Sauropoda } \\
\text { Sauropoda indet. (= Astrodon sp., } \\
\text { Rebbachisaurus tamesnensis, } \\
\text { Aegyptosaurus baharijensis) } \\
\text { Ankylosauria } \\
\text { Nodosauridae indet. }\end{array}$ & Albian-early Cenomanian & 18 & -9 \\
\hline 6 & Antenor Navarro Formation & Estado do Ceará, Brazil & $\begin{array}{l}\text { therapod tracks } \\
\text { euornithopod tracks }\end{array}$ & pre-Aptian & -5 & -39 \\
\hline 7 & Santana Formation & Estado do Ceará, Brazil & $\begin{array}{l}\text { Therapoda } \\
\text { Spinosauridae } \\
\text { Irritator challengeri } \\
\text { Angaturama limai } \\
\text { unnamed compsognathid } \\
\text { ?Tyrannosauroidea } \\
\text { Santanaraptor placidus } \\
\text { ?Oviraptorosaurida indet. } \\
\text { ?Ornithischia indet. }\end{array}$ & ?Albian & -5 & -39 \\
\hline 8 & Tadi Beds & Iembe, Angola & Diplodocoidea & Turonian-Coniacian & -8 & 13 \\
\hline 9 & Mocuio Formation & Bentiaba, Angola & Dinosauria indet. & Campanian-Maastrichtian & -14 & 12 \\
\hline 10 & Hidden Lake Formation & $\begin{array}{l}\text { James Ross Island, } \\
\text { Antarctic Peninsula } \\
\end{array}$ & Therapoda indet. & Coniacian-Santonian & -64 & -56 \\
\hline 11 & Santa Marta Formation & $\begin{array}{l}\text { James Ross Island, } \\
\text { Antarctic Peninsula }\end{array}$ & $\begin{array}{l}\text { Ankylosauria } \\
\text { Nodosauridae indet. }\end{array}$ & late Campanian & -64 & -56 \\
\hline 12 & López de Bertodano Formation & $\begin{array}{l}\text { Vega Island, } \\
\text { Antarctic Peninsula }\end{array}$ & $\begin{array}{l}\text { Ornithopoda } \\
\text { Euornithopoda } \\
\text { undescribed euornithopodan } \\
\text { Hadrosauridae indet. }\end{array}$ & $\begin{array}{l}\text { late Campanian- } \\
\text { early Maastrichtian }\end{array}$ & -64 & -56 \\
\hline 13 & Knollenmergel & Switzerland & Prosauropoda indet. & late Norian & 48 & 8 \\
\hline 14 & Obere Bunte Mergel & Switzerland & $\begin{array}{l}\text { Theropoda indet. (=cf. } \\
\text { Liliensternus } \mathrm{sp} .) \\
\text { Prosauropoda } \\
\text { Plateosaurus } \text { cf. longiceps }\end{array}$ & late Norian & 48 & 8 \\
\hline
\end{tabular}


TABLE I (continuation)

\begin{tabular}{|c|c|c|c|c|c|c|}
\hline \# & Formation & Location & Taxa & $\overline{\text { Age }}$ & Lat & Lon \\
\hline 15 & Zanclodonmergel & Switzerland & $\begin{array}{l}\text { Prosauropoda } \\
\quad \text { Plateosaurus sp. }\end{array}$ & late Norian & 48 & 8 \\
\hline 16 & unnamed unit & Switzerland & $\begin{array}{l}\text { Therapoda } \\
\text { ?Tetanurae indet. } \\
\text { Prosauropoda } \\
\text { Plateosaurus sp. } \\
\text { ?Ornithopoda } \\
\text { ?Heterodontosauridae indet. (= } \\
\quad \text { ?Abrictosaurus sp.) }\end{array}$ & ?late Norian-Hettangian & 48 & 8 \\
\hline 17 & unnamed unit & Switzerland & Therapoda indet. & ?Oxfordian & 48 & 8 \\
\hline 18 & unnamed unit & Switzerland & Therapoda indet. & Oxfordian & 48 & 8 \\
\hline 19 & unnamed unit & Switzerland & Stegosauria indet. & late Oxfordian & 48 & 8 \\
\hline 20 & unnamed unit & Switzerland & Therapoda indet. & early Kimmeridgian & 48 & 8 \\
\hline 21 & Reuchenette Formation & Switzerland & $\begin{array}{l}\text { therapod tracks } \\
\text { sauropod tracks }\end{array}$ & Middle-late Kimmerdgian & 48 & 8 \\
\hline 22 & Villigen Formation & Switzerland & Stegosauria indet. & late Oxfordian & 48 & 8 \\
\hline 23 & Reuchenette Formation & Switzerland & $\begin{array}{l}\text { Therapoda } \\
\text { Tetanurae indet. (= } \\
\quad \text { Megalosaurus meriani) } \\
\text { therapod tracks } \\
\text { sauropod tracks }\end{array}$ & Middle-late Kimmerdgian & 48 & 8 \\
\hline 24 & Upper Schrattenkalk Formation & Switzerland & euornithopod tracks & late Aptian & 48 & 8 \\
\hline 25 & San Giovanni Rotondo Formation & Regione Puglia, Italy & $\begin{array}{l}\text { therapod tracks } \\
\text { ?ornithopod tracks }\end{array}$ & $\begin{array}{l}\text { late Hauterivian- } \\
\text { early Barremian }\end{array}$ & 41 & 16 \\
\hline 26 & Calcare di Altamura & Regione Puglia, Italy & $\begin{array}{l}\text { ?sauropod tracks } \\
\text { ?ankylosaur tracks } \\
\text { hadrosaur tracks }\end{array}$ & late Santonian & 41 & 16 \\
\hline 27 & Tegana Formation & Ksar-es-souk, Morocco & $\begin{array}{l}\text { Therapoda } \\
\text { Allosauroidea } \\
\quad \text { Carcharodontosaurus saharicus } \\
\text { Sauropoda } \\
\text { Diplodocoidea } \\
\quad \text { Rebbachisaurus garasbae }\end{array}$ & Albian-Cenomanian & 32 & -4 \\
\hline 28 & Upper Kem-Kem Beds & Ksar-es-souk, Morocco & $\begin{array}{l}\text { Therapoda } \\
\text { Carnosauria } \\
\text { Carcharodontosaurus saharicus } \\
\text { Coelurosauria incertae sedis } \\
\text { Deltadromeous agilis } \\
\text { Dromaeosauridae indet. } \\
\text { theropod tracks } \\
\text { Sauropoda } \\
\text { undescribed sauropods } \\
\text { Sauropoda indet. (= } \\
\text { Rebbachisaurus sp.) } \\
\text { sauropod tracks } \\
\text { Ornithopoda } \\
\text { undescribed iguantodontian } \\
\text { euornithopod tracks }\end{array}$ & Cenomanian & 32 & -4 \\
\hline 29 & Continental Red Beds & Ksar-es-souk, Morocco & $\begin{array}{l}\text { Therapoda } \\
\text { Ceratosauria } \\
\text { Abelisauridae indet. (including cf. } \\
\text { Majungasaurus } \text { sp.) } \\
\text { Tetanurae } \text { incertae sedis } \\
\text { Sigilmassasaurus brevicollis } \\
\text { Sigilmassasaurus } \text { sp. } \\
\text { Spinosauridae } \\
\text { Spinosaurus maroccanus } \\
\text { Spinosaurus } \text { cf. aegyptiacus } \\
\text { Spinosaurus } \text { sp. } \\
\text { Carnosauria } \\
\text { Carcharodontosaurus saharicus } \\
\text { Carcharodontosaurus } \text { sp. } \\
\text { ?Carcharodontosaurus } \text { sp. } \\
\text { Theropoda indet. (including cf. } \\
\text { Elaphrosaurus } \text { sp.) }\end{array}$ & Cenomanian & 32 & -4 \\
\hline
\end{tabular}


TABLE I (continuation)

\begin{tabular}{|c|c|c|c|c|c|c|}
\hline$\#$ & Formation & Location & Taxa & Age & Lat & Lon \\
\hline 29 & Continental Red Beds & Ksar-es-souk, Morocco & $\begin{array}{l}\text { Sauropoda } \\
\text { Lithostrotia indet. (= } \\
\text { Titanosauridae indet.) } \\
\text { Sauropoda indet. (including } \\
\text { Rebbachisaurus } \text { sp.) }\end{array}$ & Cenomanian & 32 & -4 \\
\hline 30 & unnamed unit & Mechooz Yerushalayim, Israel & therapod tracks & early Cenomanian & 32 & 35 \\
\hline 31 & Tendaguru Formation & Mkoawa Mtwara, Tanzania & $\begin{array}{l}\text { Therapoda } \\
\text { Ceratosauria } \\
\text { Elaphrosaurus bambergi } \\
\text { Ceratosaurus sp. (= Ceratosaurus } \\
\text { roechlingi, Labrosaurus stechowi) } \\
\text { Allosauroidea } \\
\text { ?Allosaurus tendagurensis } \\
\text { Therapoda indet. (= } \\
\text { Megalosaurus ingens) } \\
\text { Sauropoda } \\
\text { Sauropoda incertae sedis } \\
\text { Tendaguria tanzaniensis } \\
\text { Diplodocoidea } \\
\text { Dicraeosaurus hansemanni } \\
\text { Dicraeosaurus sattleri } \\
\text { Tornieria africanus } \\
\text { Barosaurus brancai } \\
\text { Titanosauria } \\
\text { Janenschia robusta } \\
\text { Stegosauria } \\
\text { Stegosauridae } \\
\text { Kentrosaurus aethiopicus } \\
\text { Ornithopoda } \\
\text { Iguantodontia } \\
\text { Dryosaurus lettoworbecki } \\
\text { ?dinosaur eggs }\end{array}$ & Kimmeridgian & -11 & 39 \\
\hline 32 & Isalo III Formation & Faritany Majunga, Madagascar & $\begin{array}{l}\text { Therapoda } \\
\text { ?Allosauroidea indet. } \\
\text { Sauropoda } \\
\text { Titanosauriformes } \\
\text { Lapparentosaurus madagascarensis } \\
\text { Sauropoda indet. (= Bothriospondylus } \\
\text { madagascarensis) }\end{array}$ & Bathonian & -16 & 47 \\
\hline 33 & Ankarafantsika Formation & Faritany Majunga, Madagascar & Sauropoda indet. & Cenomanian & -16 & 47 \\
\hline 34 & Ankazomihaboka & Faritany Majunga, Madagascar & $\begin{array}{l}\text { Therapoda indet. (including } \\
\text { Majungasaurus crenatissimus) } \\
\text { Sauropoda } \\
\text { Lithostrotia } \\
\text { "Titanosaurus" madagascarensis }\end{array}$ & Coniacian & -16 & 47 \\
\hline 35 & Maevarano Formation & Faritany Majunga, Madagascar & $\begin{array}{l}\text { Therapoda } \\
\text { Ceratosauria } \\
\text { Majungasaurus atopus } \\
\text { Masiakasaurus knopfleri } \\
\text { Majungasaurus crenatissimus } \\
\text { ?Spinosauridae indet. } \\
\text { Sauropoda } \\
\text { Lithostrotia } \\
\text { Rapetosaurus kraussei } \\
\text { "Titanosaurus" madagascarensis } \\
\text { undescribed lithostrotian } \\
\text { Lithostrotia indet. (= } \\
\text { Titanosauridae indet.) } \\
\text { ?Ornithischia indet. (= Stegasaurus } \\
\text { madagascarensis) }\end{array}$ & Campanian & -16 & 47 \\
\hline 36 & Tiki Formation & Madha Predesh, India & Therapoda indet. & Carnian & 23 & 84 \\
\hline 37 & Kaladongar Formation & Gujarat, India & Dinosauria indet. & Aalenian-Bathonian & 22 & 77 \\
\hline 38 & Patcham Formation & Gujarat, India & dinosaur eggs & Bathonian & 22 & 77 \\
\hline 39 & Chari Formation & Gujarat, India & Sauropoda indet. & Callovian & 22 & 77 \\
\hline
\end{tabular}


TABLE I (continuation)

\begin{tabular}{|c|c|c|c|c|c|c|}
\hline \# & Formation & Location & Taxa & Age & Lat & Lon \\
\hline 40 & Lameta Formation & Gujarat, India & $\begin{array}{l}\text { Therapoda } \\
\text { Ceratosauria } \\
\text { Rajasaurus narmadensis } \\
\text { Ceratosauria indet. (= } \\
\text { Majungasaurus crenatissimus) } \\
\text { undescribed abelisaurids } \\
\text { Therapoda indet. (= } \\
\text { Megalosaurus sp.) } \\
\text { Sauropoda indet. (= Titanosaurus } \\
\text { rahioliensis) } \\
\text { sauropod tracks } \\
\text { Ankylosauria } \\
\text { undescribed ?ankylosaurid } \\
\text { dinosaur eggs }\end{array}$ & Maastrichtian & 22 & 77 \\
\hline 41 & Wagad Formation & Gujarat, India & $\begin{array}{l}\text { ?sauropod tracks } \\
\text { ?euornithopod tracks }\end{array}$ & Maastrichtian & 22 & 77 \\
\hline 42 & Anjar Formation & Gujarat, India & $\begin{array}{l}\text { undescribed saurischians } \\
\text { undescribed ornithischians } \\
\text { dinosaur eggs }\end{array}$ & Maastrichtian & 22 & 77 \\
\hline 43 & Katrol Formation & Gujarat, India & $\begin{array}{l}\text { ?sauropod tracks } \\
\text { ?euornithopod tracks }\end{array}$ & Maastrichtian & 22 & 77 \\
\hline 44 & Bhuj Formation & Gujarat, India & $\begin{array}{l}\text { ?sauropod tracks } \\
\text { ?euornithopod tracks }\end{array}$ & Maastrichtian & & \\
\hline 45 & Hanson Formation & Transantarctic Mountains, Antarctica & $\begin{array}{l}\text { Therapoda } \\
\text { Carnosauria } \\
\text { Cryolophosaurus ellioti } \\
\text { Allosauroidea indet. } \\
\text { Therapoda indet. } \\
\text { Prosauropoda indet. } \\
\end{array}$ & Sinemurian-Pliensbachian & -84 & 166 \\
\hline 46 & Wonthaggi Formation & Victoria, Australia & $\begin{array}{l}\text { Therapoda } \\
\text { Allosauroidea indet. } \\
\text { Ornithomimosauria indet. } \\
\text { Dromaeosauridae indet. } \\
\text { Therapoda indet. } \\
\text { Ankylosauria indet. } \\
\text { Ornithopoda } \\
\text { Euornithopoda } \\
\text { Fulgurotherium australe } \\
\text { Qantassaurus intrepidus } \\
\text { Fulgurotherium sp. } \\
\text { ?Ceratopsia } \\
\text { ?Neoceratopsia indet. (= } \\
\text { Serendipaceratops arthurclarkei) }\end{array}$ & Valanginian-Aptian & -38 & 146 \\
\hline 47 & Eumeralla Formation & Victoria, Australia & $\begin{array}{l}\text { Therapoda } \\
\text { Ornithomimosauria indet. (= } \\
\text { Timimus hermani) } \\
\text { ?Oviraptorosauria indet. } \\
\text { ?Dromaeosauria indet. } \\
\text { ornithischian tracks } \\
\text { Ornithopoda } \\
\text { Euornithopoda } \\
\text { Leaellynasaura amicagraphica } \\
\text { Atlascoposaurus loadsi } \\
\text { dinosaur tracks }\end{array}$ & early Albian & -38 & 146 \\
\hline 48 & Tahora Formation & North Island, New Zealand & $\begin{array}{l}\text { Therapoda indet. } \\
\text { Sauropoda indet. } \\
\text { Ankylosauria } \\
\text { Nodosauridae indet. } \\
\text { Ornithopoda } \\
\text { Iguantodontia indet. }\end{array}$ & Campanian & -39 & 176 \\
\hline 49 & & Horn of Africa, Somalia & & & 11 & 51 \\
\hline 50 & & Karachi, Pakistan & & & 25 & 67 \\
\hline 51 & & Peshawar, Pakistan & & & 34 & 71 \\
\hline
\end{tabular}




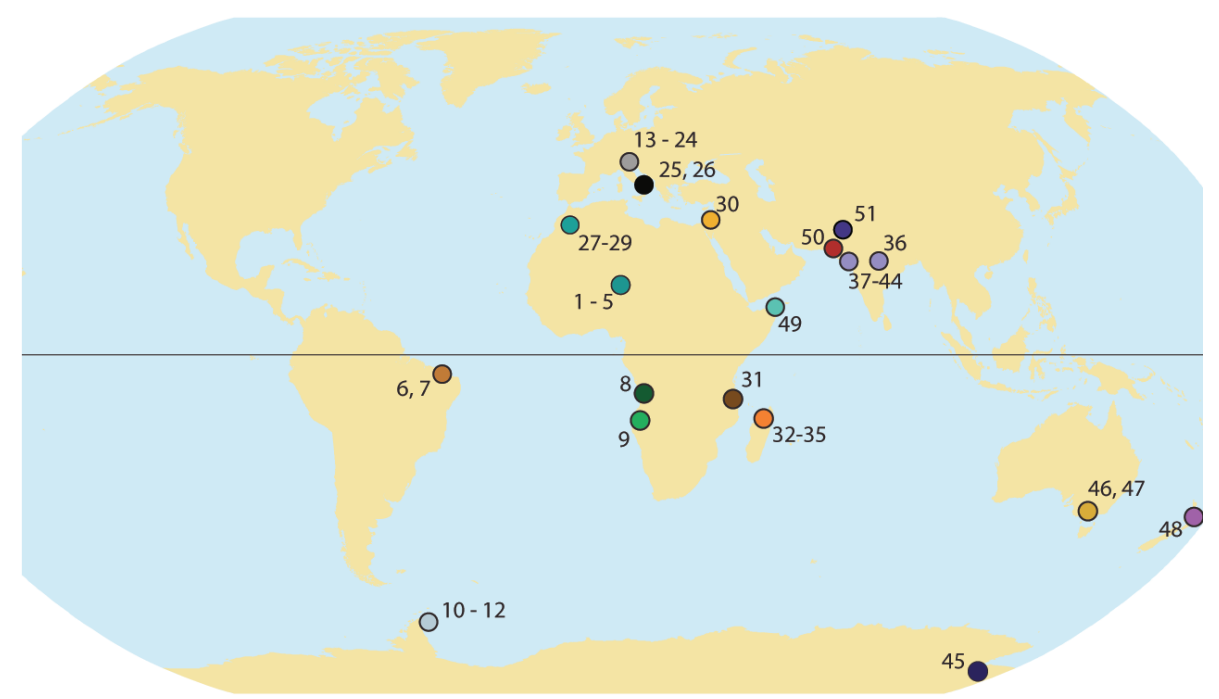

Fig. 1 - Modern distribution of Gondwana dinosaur localities (listed by number in Table I) used in this study.

dition to spatial uncertainties, imprecision in the age of a fossil locality is also inherent in the plots, although this is not considered to be a major problem for current purposes. Where an age range is reported (Weishampel et al. 2004), we use the mid-point of the age range in constructing the plots. We have not updated the faunal lists from Weishampel et al. (2004), nor have we made detailed comparisons of the taxonomic composition between localities. Any attempt at phylogeographic analysis is beyond the scope of this paper.

\section{RESULTS}

Figure 2 shows the opening of the South Atlantic by tracing points that now fall in conjugate basins in South America and Africa. The two lines at 220 Ma represent the reconstructed positions of the Sergipe (Brazil)Gabon conjugate basins along the more northerly (lower latitude) line, and the Campos (Brazil)-Kwanza (Angola) conjugate basins along the more southerly (higher latitude) line. The parallel arching trajectories on the left of Figure 2 indicate uniform movement, the lines being parallel because the movement of the single land mass was directionally homogeneous in Pangea.

The South Atlantic opened with a counterclockwise rotation of Africa. At the paleolatitudes represented in Figure 2, the rifting between South America and Africa occurred between $132 \pm 1 \mathrm{Ma}$, the age of the Paraná-Etandeka flood basalts (Renne et al. 1996), which are associated with the modern Tristan de CunhaWalvis hotspot. The oldest magnetic anomaly found in oceanic crust adjacent to the Kwanza Basin along the African continent is chron M3 (Cande et al. 1989, Marton et al. 2000), about $128 \mathrm{Ma}$ following Gradstein et al. (2004; but could be 5-6 my younger; see Channell et al. 1995, He et al. 2008, Torsvik et al. 2009). Although rifting began earlier, the complete separation of South America and Africa occurred between $115 \mathrm{Ma}$ and $90 \mathrm{Ma}$ with the completion of the Equatorial Atlantic Gateway (Brownfield and Charpentier 2006, Jacobs et al. 2009). By $90 \mathrm{Ma}$ (Turonian), a deepwater passage developed between the southern North Atlantic and South Atlantic (Handoh et al. 1999). Africa was clearly moving north relative to South America, as indicated by the diverging continental trajectories in Figure 2. Late Aptian (115-112 Ma; Gradstein et al. 2004) marine invertebrates are found in the Sergipe Basin (Bengtson and Koutsoukos 1992, Koutsoukos 1992), which may have remained marine continuously since then (Koutsoukos et al. 1991), although there is evidence (including fossil fish, Maisey 2000) for two broader marine transgressions over Brazil during the late Aptian and Albian (Valença et al. 2003). Thus, the opening of the Atlantic at the latitudes of the Campos-Kwanza conjugate basins is between 132 and $128 \mathrm{Ma}$, while to the north, the evidence for marine conditions is no older than $115 \mathrm{Ma}$. 


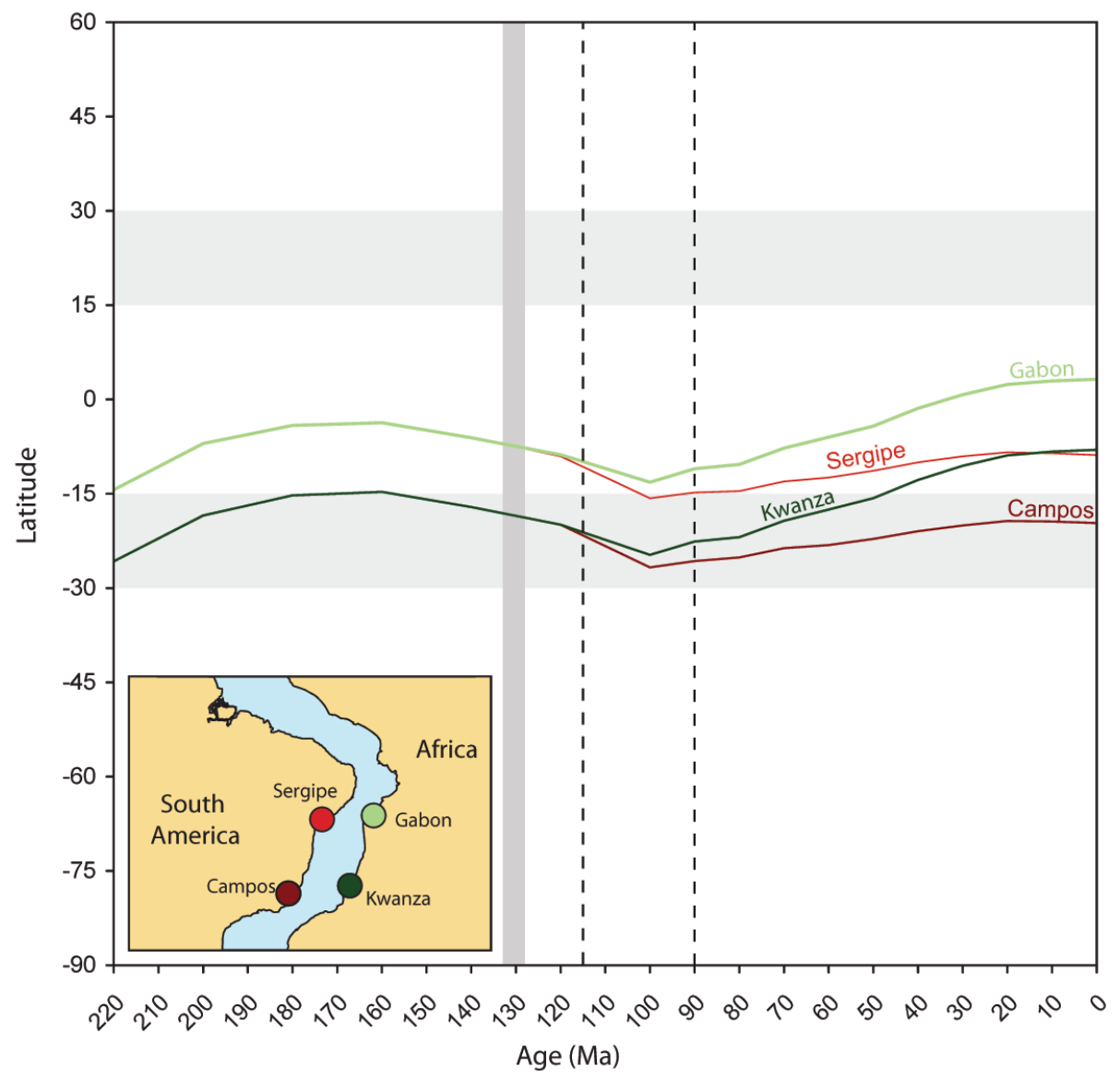

Fig. 2 - Relative motions of conjugate basins that diverged during the opening of the South Atlantic. The conjugate basins are the Sergipe (Brazil)-Gabon and the Campos (Brazil)-Kwanza (Angola). The Albian fossil localities of the Santana Formation, Brazil, are northwest of the Campos Basin. The Kwanza Basin contains the Turonian locality of Iembe. The inset map shows the position of basins during the early phase of opening of the South Atlantic Ocean. The gray shading indicates rifting at the paleolatitude of the Kwanza Basin (132-128 Ma); the dashed vertical line on left (115 Ma) indicates marine sediments in the Sergipe Basin and initiation of a shallow Equatorial Atlantic Gateway; vertical dashed line at $90 \mathrm{Ma}$ indicates completion of a deep Atlantic Equatorial Gateway.

The diverging curves after 115 Ma in Figure 2 reflect the northward drift of Africa relative to South America as the South Atlantic widened.

This example serves to demonstrate the usefulness of the method of plotting latitude trajectories through time using paleolatitudes calculated by the Point-Tracker program of PALEOMAP (Scotese 2008). The opening of the South Atlantic is perhaps the best documented of all the major oceans because the Walvis Ridge and St. Helena hotspots can be used to precisely model the relative motions between the South American and African plates (O'Connor and Duncan 1990, O'Connor and Le Roex 1992, O'Connor et al. 1999). The crossing of the Kwanza basin trace with that of the Sergipe Basin in
Figure 2 has no significance as far as rotation, but it emphasizes the northward drift of Africa.

Figure 3 tracks the famous Santana Formation localities of Araripe (6) and the older sites of the Antenor Navarro Formation (7) in the state of Ceará west of the Sergipe Basin in Brazil. We chose these Brazilian sites because they were proximal to the last point of connection with Africa. The fossil sites of Antenor Navarro were formed essentially at the Equator, at lower latitude than the lakebeds of the Albian Santana Formation. Both units were deposited as South Atlantic rifting was in its early phases, prior to the establishment of the deep water Equatorial Gateway (90 Ma) between the southern North Atlantic and the South Atlantic. All of these 


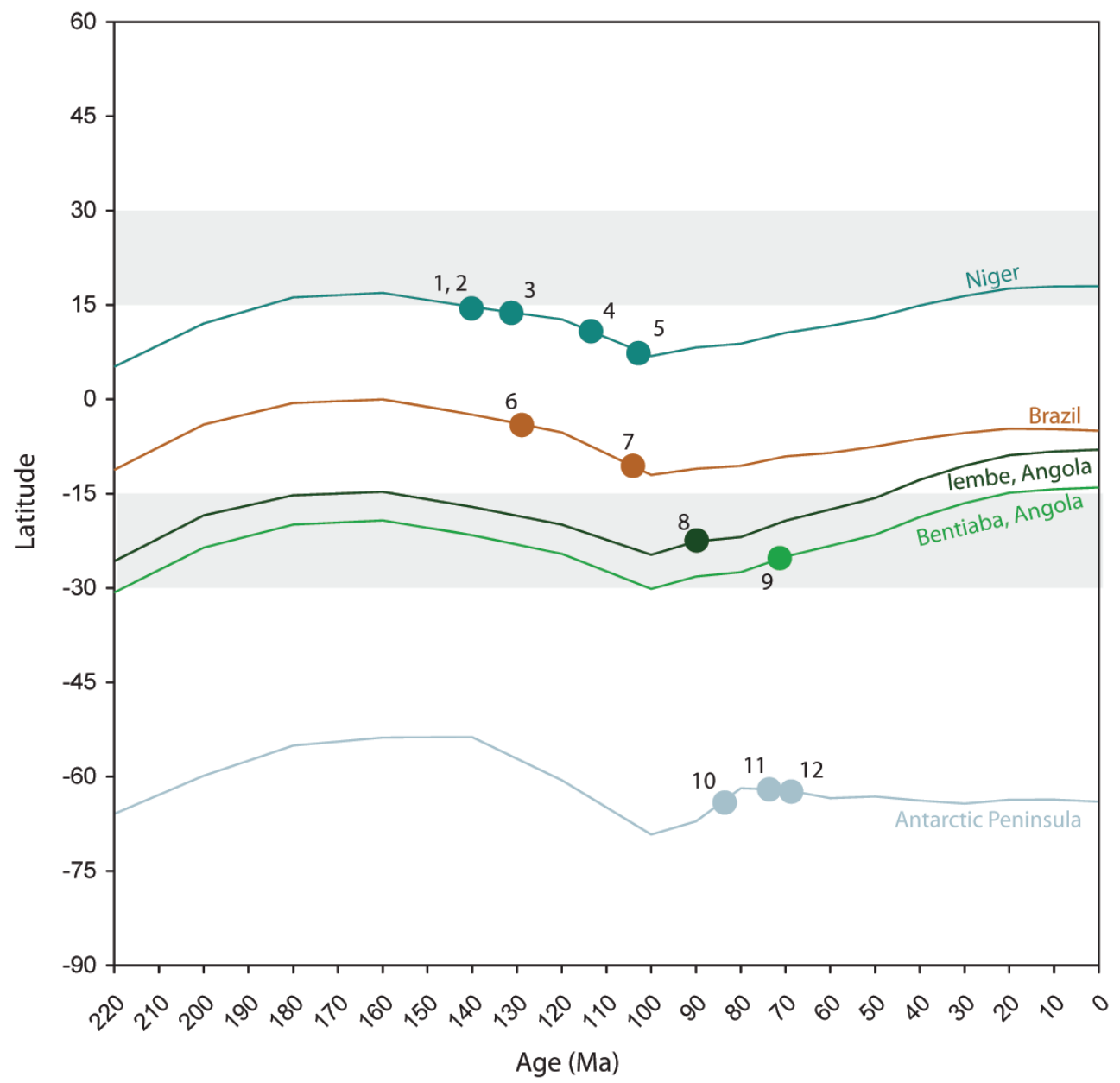

Fig. 3 - Latitudinal trajectories of Gondwana dinosaur localities (listed by number in Table I) in the South Atlantic region.

Brazilian sites have remained in the southern hemisphere tropics ever since, close to the latitudes at which they were formed, due to the fact that South America has had little northward drift. Localities farther south than Brazil in South America (not plotted) would show essentially the same trajectory as those of Brazil, offset by the latitudinal distance between sites, because South America since the Early Cretaceous moved nearly due west with very little change in latitude.

The dinosaur localities of Niger (localities 1-5) record the history of Africa from the pre-rift Late Jurassic, through to the Early Cretaceous phase of South Atlantic Ocean basin formation. None appears as young as the Late Cretaceous completion of the deep Equatorial Gateway (90 Ma). All of the Niger localities were formed at the northern edge of the tropics.
Two localities from Angola were selected, not because they are well represented by dinosaurs (they are not), but because their ages are well constrained and they were both formed under arid coastal conditions. Both localities formed in the southern arid belt. A new Turonian sauropod was found at Iembe (locality 8), which now lies in tropical latitudes $\left(8^{\circ} \mathrm{S}\right.$; Jacobs et al. 2006, 2009, Mateus et al. 2011). Only a few bones of dinosaurs have yet been found at Bentiaba (locality 9), which currently lies at the northern extreme of the Skeleton Coast or Namib Desert. These two localities illustrate the importance of recognizing the position of a stationary climate zone through which a drifting continent passes. Iembe, although tropical now, was actually formed in the desert under similar conditions to those in which the Bentiaba locality was formed. One might infer 


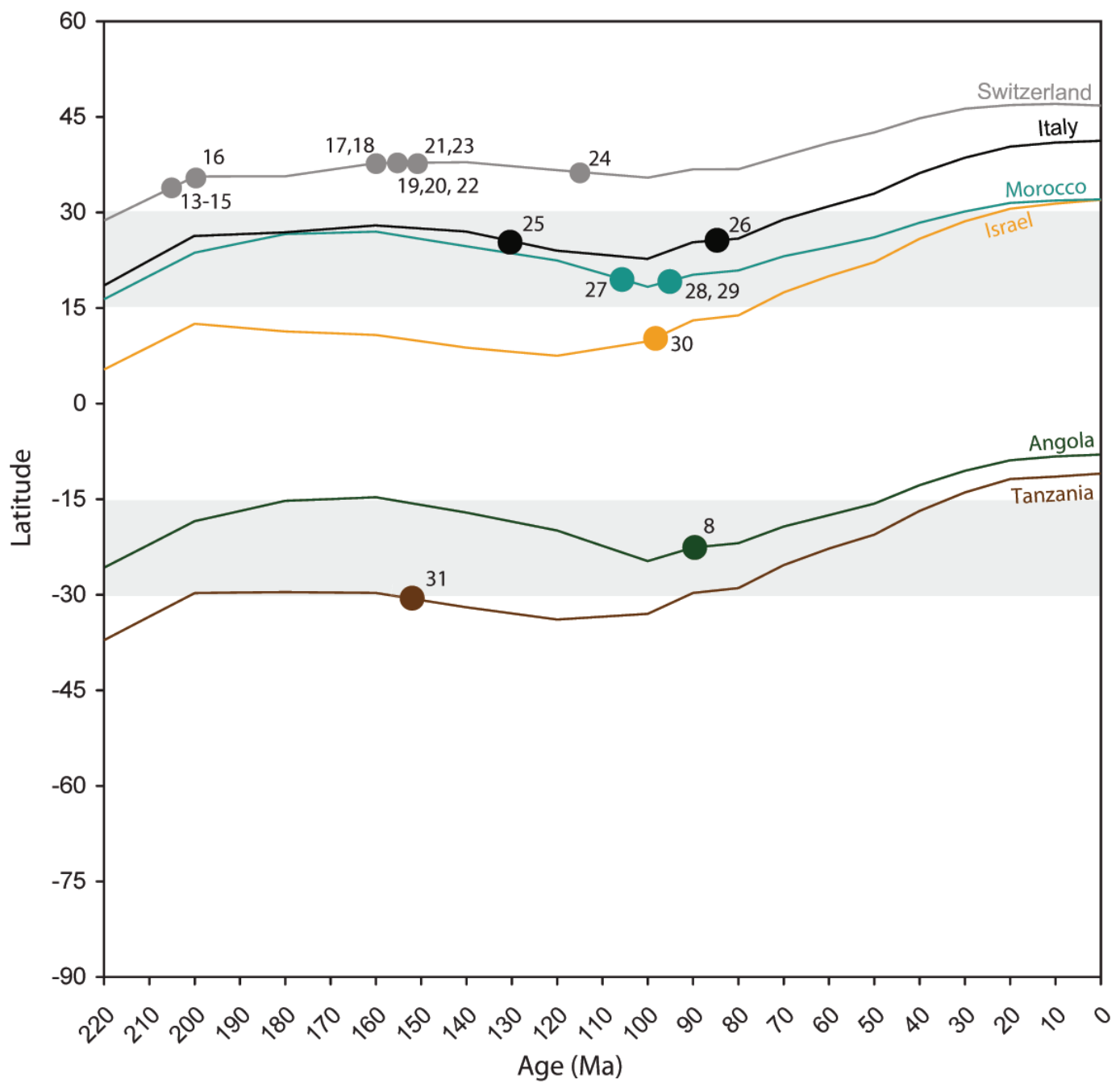

Fig. 4 - Latitudinal trajectories of Gondwana dinosaur localities and Laurasian localities in Switzerland (13-24) around the Mediterranean Sea region (localities listed by number in Table I).

that the sauropod from Iembe inhabited a coastal desert and had a lifestyle similar to desert elephants that now inhabit the Skeleton Coast of Namibia.

Three Late Cretaceous localities in Figure 3 are known from present day islands along the east side of the Antarctic Peninsula (localities 10, 11 and 12). The dinosaurs from these localities are from the region of Antarctica that is closest to South America. The Antarctic Circle falls between $66^{\circ}$ and $67^{\circ} \mathrm{S}$. It appears that the Antarctic Peninsula localities were formed at the edge of the Antarctic Circle and have not changed latitude significantly since that time.

Figure 4 shows three Moroccan fossil localities (27-29) formed in the northern arid zone, as the Equato- rial Gateway developed. These localities have remained in arid latitudes throughout their subsequent history. By comparing the latitudinal trajectories of localities from Morocco and Angola, it is clear that Africa straddled both the northern and southern limbs of Hadley Cells during the Cretaceous. No other continental landmass since Pangea has had that distinction.

The Triassic to Cretaceous localities in Switzerland (13-27) are not Gondwanan, but rather represent the southernmost border of Eurasia. The localities in the Regione Puglia $(25,26)$ of southern Italy are Gondwanan and their northward trajectory represents the transfer of this terrane from the African Plate to the Eurasian plate. This is a classic example of a Beached 
Viking Funeral Ship. Early Cretaceous fossils found on these Gondwana microcontinents are representative of the Cretaceous fauna of Africa, and are not informative in any simple way of the European Cretaceous fauna (Polcyn et al. 1999). The exotic terranes of Regione Puglia, Italy, were formed in the northern arid zone although they now lie in a Mediterranean climate. While it is clear that this is an example of a Beached Viking Funeral Ship, it is not clear at all whether this transfer also represents a Noah's Ark because there is no phylogenetic or historical evidence to suggest an introduction of southern elements into the contemporaneous biota at the time of docking. The microcontinents that formed southern Europe all appear to have been of low relief and may have been subjected to total marine inundations that would have annihilated the terrestrial biota and rendered these arks into ghost ships, at least as far as non-avian dinosaurs are concerned.

The Jurassic locality of Tendaguru (31) is included in Figure 4 because it lies near the eastern coast of Africa close to the same latitude as that of Iembe (8), Angola, on the western coast. It provides continuity with Figures 5 and 6 . Tendaguru formed at the southern limit of the arid latitudes. The convergence of the Iembe and Tendaguru traces is due to counterclockwise rotation of Africa. The trace of the Middle Eastern locality of Mechooz Yerushalayim (31) converges with the trace of Moroccan localities for the same reason; i.e., the counterclockwise rotation of Africa during the Late Cretaceous.

The emphasis in Figure 5 is on Antarctica, Australia, and New Zealand. The trajectories of the Antarctic Peninsula (localities 10-12) and the Transantarctic Mountains (45) cross during the Jurassic indicating rotation of the single landmass, followed by a generally southward drift as Australia-plus-Antarctica move toward the South Pole. These localities reach their maximum southerly latitude during the Early Cretaceous (pre-Aptian). During the Campanian $(80 \mathrm{Ma})$ all the southern Gondwana dinosaur sites occupy latitudes of 60 to 65 degrees South.

Localities of Australia $(46,47)$ and New Zealand (48) occupy land that travelled in concert, moving southward throughout the Jurassic into the Early Cretaceous. Beginning in the Early Cretaceous (140-130 Ma) Aus- tralia and New Zealand began to drift northward as the southeast Indian Ocean began to open. As a result of the opening of the Tasman Sea (100-60 Ma), New Zealand drifted into lower latitudes during the Late Cretaceous.

The most southerly dinosaur locality is from the Wonthaggi Formation, Early Cretaceous of Australia (46). The Wonthaggi dinosaur fauna lived at latitudes approaching 80 degrees as shown by the trajectory in Figure 5. Throughout the Cretaceous, Australian localities moved steadily northward. Dinosaurs of the Tahora Formation on the North Island, New Zealand (48), were originally at about $60^{\circ} \mathrm{S}$, clustering in paleolatitude and age with the dinosaur localities of the Antarctic Peninsula.

Dinosaurs from Australia, New Zealand, and Antarctica lived at high paleolatitudes and were subject to environmental conditions not found at lower latitudes (Rich and Vickers-Rich 2000). Although the fossil remains of Transantarctic dinosaurs are now found at southern polar latitudes, they lived in high temperate paleolatitudes. The trajectory of the Transantarctic Mountains locality (45) shows that in the Jurassic it was located at $60^{\circ} \mathrm{S}$ and has moved steadily poleward since that time.

Figure 6 illustrates paleogeographic features associated with the breakup of eastern Gondwana involving Africa, India, Madagascar, and Australia. The trajectories of the India-plus-Madagascar localities cross the Tanzania trajectory because, during the Jurassic initial breakup of Gondwana, India together with Madagascar moved to the south, opening the Somali Basin. The trajectories of India, Madagascar, and Australia are parallel from Triassic until the Early Cretaceous when India, Madagascar, and Australia rifted away as a unit. By $90 \mathrm{Ma}$ (Turonian), India and Madagascar separated and India began its very rapid northward journey (see also Krause et al. 2006). After its split with India, Madagascar was fixed to Africa. All four of these landmasses moved northward from the Cretaceous to the present day. Africa and Madagascar have travelled as a unit. Australia rifted from Antarctica about 50 million years ago and then moved relatively rapidly with India toward Asia.

The distribution of localities at Majunga, Madagascar (32-35), Gujarat, India (37-44), and Tendaguru, Tanzania (31) shows a Jurassic cluster of localities that 


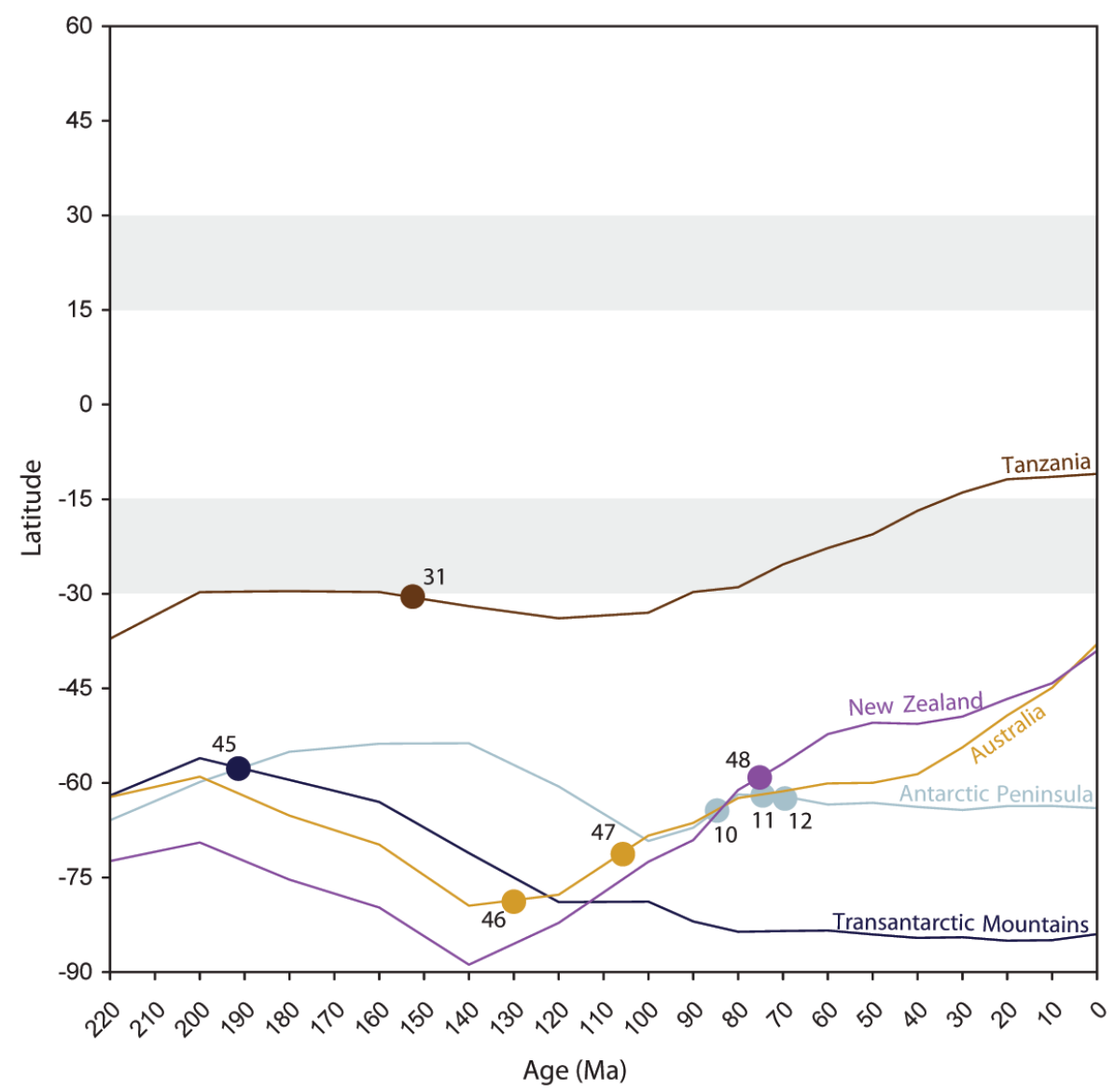

Fig. 5 - Trajectories of localities in the far South Atlantic (Antarctic Peninsula, 10-12) and the eastern Indian Ocean (Transantarctic Mountains, 45; Australia, 46, 47; and New Zealand, 48). The motion of the sites can be compared with the latitudinal shift of Tendaguru (35), a locality in southeastern Africa.

formed in the southern arid latitudes. The Cretaceous fossil localities of Gujarat were also formed in the southern arid zone, but now lie in the northern arid zone. The Indian localities joined Asia in a Beached Viking Funeral Ship.

The size, relief, and emergence of the Indian subcontinent insure that it was also a Noah's Ark as it moved from Gondwana to Asia. Nevertheless, because its journey was of such long duration, the fossil vertebrate record of India houses a suite of species from different ages that reflect distinct biogeographic histories. The Triassic dinosaurs and associated fossils of India are true voyagers on a Beached Viking Funeral Ship, being derived from Pangaea at least 220 million years ago. The Jurassic dinosaurs of India-Madagascar represent younger-aged participants in the same Viking Funeral ship and are bio- geographically similar to those of Tendaguru. After the split from eastern Gondwana in the Early Cretaceous, India-Madagascar shared the same Noah's Ark fauna, until their late Cretaceous separation, after which the youngest dinosaurs of each have had separate Noah's Ark-type histories. India, with its older vertebrate fossil record, is clearly a Beached Viking Funeral Ship. It is also a Noah's Ark because it carried a fauna to the doorstep of Asia.

The known Cretaceous fauna of India is more cosmopolitan than endemic. Therefore, Chatterjee and Scotese (1999, see also Briggs 2003) suggested that India collided with Greater Somalia, an eastward extension of Africa, near the end of the Cretaceous, allowing interchange with Africa before India's final excursion north. In a later paper, Chatterjee and Scotese (2009) reject 


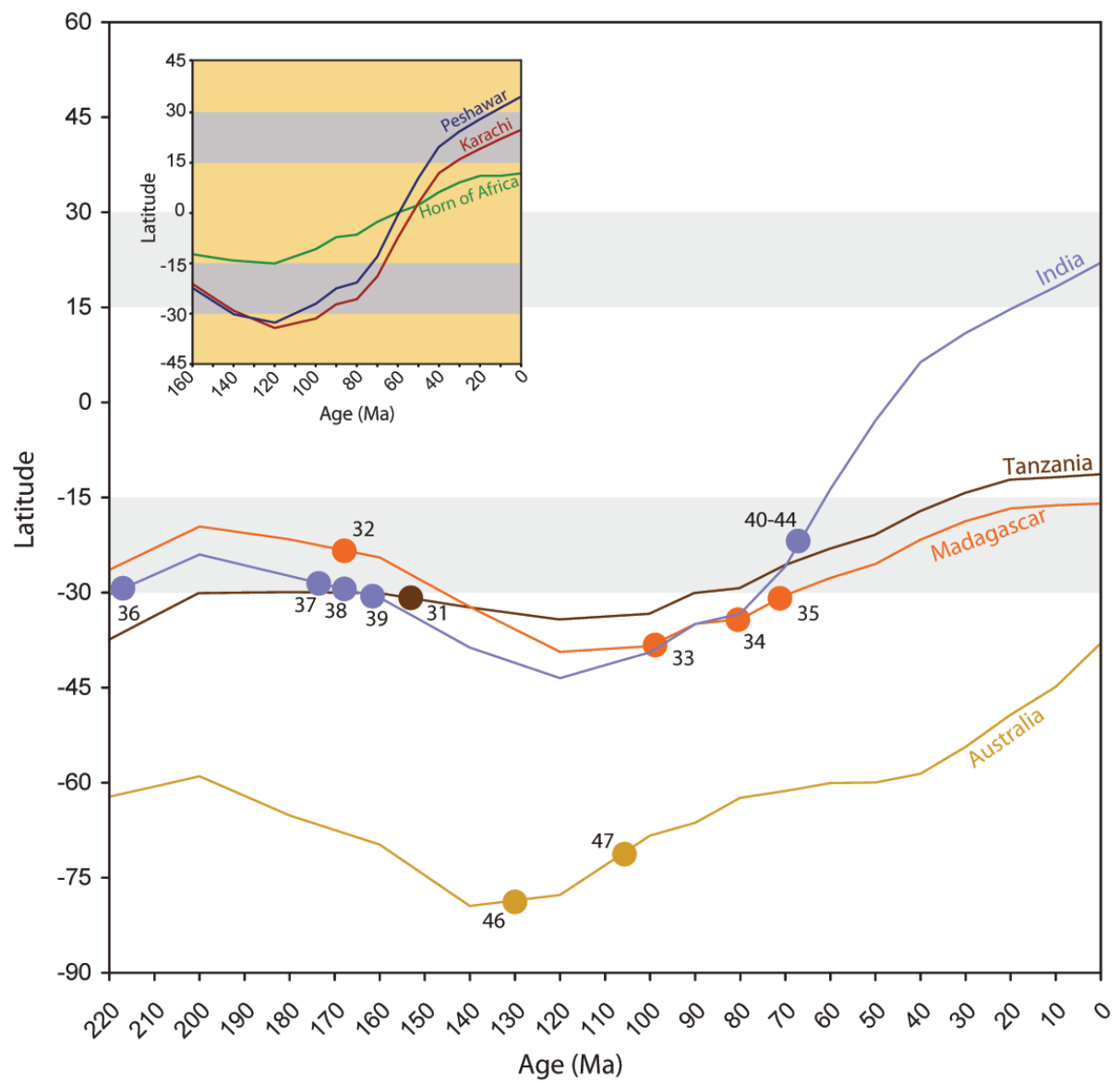

Fig. 6 - Latudinal trajectories of Gondwana dinosaur localities in the region of the Indian Ocean (localities listed by number in Table I). The inset shows the latitudinal trajectory of Karachi on the western margin of the Indian Subcontinent, of Peshawar near the Hindu Kush, and of the Horn of Africa, the easternmost part remaining of Greater Somalia. The trajectories cross in the early Paleogene indicating that the dispersal of dinosaurs from Africa to India by this route is unlikely if the points used accurately reflect paleogeography.

the Greater Somalia hypothesis in favor of an OmanKohistan-Dras Island Arc, represented in its western portion by the Semail ophiolite of Oman. In that case, faunal dispersal would have occurred across the island arc between eastern Africa and India during the Maastrichtian. Both cases depend on a justaposition of land during the appropriate time interval.

We compared the latitudinal drift of the Indian Subcontinent at Karachi, along the Indian Ocean coast, and at Peshawar, near the Hindu Kush, to the eastern extent of Somalia at the Horn of Africa and with the Semail Ophiolite, Oman (Fig. 6, inset). The surface area of the Indian subcontinent was reduced by collision with Asia (Chatterjee and Scotese 2009), but if the locations of Karachi or Peshawar approximate a path of faunal dispersal, then they should lie at the same paleolatitude as the Horn of Africa or Oman at the end of the Cretaceous, which would be indicated by the crossing of their traces. As shown, the traces cross in the early Paleogene at a paleolatitude close to the Equator. Without modification of the shape of the Indian subcontinent, this is too late for the proposed hypothesis to affect dinosaurs, but appropriate for Cenozoic mammals and other terrestrial vertebrates of the time, if it occurred.

\section{DISCUSSION}

In this contribution, we have attempted to look at paleogeographic data relating to the breakup of Gondwana and the distribution of dinosaurs in a new way, by using the Point Tracker program (Scotese 2008) in the light of McKenna's Noah's Ark and Viking Ship concepts. 
We have presented large-scale trends that emerge with timescales of $10^{8}$ years, the time it takes for supercontinents to break apart and disperse, even though the localities themselves represent single points on a time and geographic continuum. We are able to compare the histories of widely separated localities with respected to when, where, and under what broad climatic regimes they were formed, and we have used the method to test a previous hypothesis.

The determining factor differentiating McKenna's concepts of Noah's Arks and Viking Ships is whether the organisms were already fossils in the geographic context from which the fauna embarked on its paleogeographic trajectory. The Jurassic localities of India plotted on Figure 6 were transported to Asia as if on a Beached Viking Funeral Ship from Pangea. The Cretaceous localities of India have a fauna that began as passengers on a biogeographic Noah's Ark, most likely derived largely from the living biota at the time Madagascar and India were still joined (Krause et al. 2006), but seemingly modified by later exchanges (Chatterjee and Scotese 2009). The 30 million-year northward drift of India provided time and context for extinction, origination, and introduction of new species. Dinosaurs afloat and evolving on the Cretaceous Indian ark were fossils by the time it docked with Asia, thus arriving on a ghost ship.

The localities of Regione Puglia, Italy (Fig. 4), present an apparent case of a biogeographic Beached Viking Funeral Ship because these localities formed at the northern edge of Gondwana, broke away on a microcontinent, traversed the Neotethys Sea, collided with Europe as it existed then, and formed an accreted terrane that is now southern Europe. Those species living on the microcontinent were passengers on a Noah's Ark. Which species, if any, may have been transported to southern Europe is not known. However, low lying islands subside with time, so the microcontinent on which the Regione Puglia localities were transported may have been inundated during its voyage, extirpating or driving extinct the entire terrestrial fauna after its departure and docking. This, as in the case of Late Cretaceous dinosaurs in India, is an extension of McKenna's dispersalist concepts. We define a biogeographic Ghost Ship as a Noah's Ark in which the original fauna is extinct at docking, whether preserved as fossils or not.
Two alternative models have been invoked to explain the distribution of dinosaurs, most especially abelisaurids, among South America, Africa, and Madagascar. In the Africa-first model (Sampson et al. 1998, Krause et al. 2006), Africa is seen to have become isolated while the remainder of Gondwana was still conjoined. The isolation of Africa began first along the Indian Ocean coast, south around the Cape of Good Hope, then northward through the South Atlantic. The final connection to greater Gondwana was at the Equatorial Atlantic Gateway. At this time in the Early Cretaceous, South America was connected to Antarctica through the Antarctic Peninsula, Antarctica was joined to Australia, and India and Madagascar were conjoined to each other and to Australia. Theoretically, this paleogeographic arrangement would allow southern dispersal from South America to Madagascar and India without recourse to Africa. Thus, Africa would have been a separate theater of evolution for its terrestrial fauna, independent of the rest of Gondwana.

The alternative to the Africa-first model, the panGondwana model of Sereno et al. (2004), posits a younger connection between Africa and South America, thereby explaining the presence of the abelisaurid Rugops in the Echkar Formation, Niger. The age of the Echkar Formation is given as Cenomanian by Sereno et al. (2004) with a numerical value of $95 \mathrm{Ma}$, within the range of the Cenomanian given by Gradstein et al. (2004). However, there are no published radiometric dates for the Echkar, and the age given by Taquet (1976) for the Echkar is Albian. It is unclear whether either the Africa-first or pan-Gondwana hypothesis is completely or partially correct, especially if the connections between landmasses are seen as tectonically controlled landspans; that is, a series of off-shelf islands occasionally connected because of sea level fluctuation and thermal buoyancy, rather than classic biogeographic corridors or filters.

It is possible that landspans are a general feature of rifting landmasses and tectonically active oceanic areas. Relief and off-shelf island formation results from volcanism, thermal uplift, and faulting, as in the hypothesized Oman-Kohistan-Dras Island Arc. Off-shelf islands are not part of the continental shelf, and although they may be affected by tectonic events that also affect nearby con- 
TABLE II

Chronological Sequence of Events in the Opening of the Equatorial Atlantic Gateway.

\begin{tabular}{l|l|l}
\hline Age (Ma) & \multicolumn{1}{|c}{ Stage } & \multicolumn{1}{c}{ Event } \\
\hline 220 & Carnian & Pangea already complete \\
\hline $147-106$ & Tithonian-Albian & Benue volcanics, $1^{\text {st }}$ phase \\
\hline $132 \pm 1$ & Hauterivian & Etandeka Basalts \\
\hline 128 & Barremian & Oldest oceanic crust (Chron M3) \\
\hline $115-112$ & Late Aptian & Sergipe basin marine \\
\hline $112-100$ & Albian & $2^{\text {nd }}$ South American transgression \\
\hline $115-90$ & Late Aptian-Turonian & Shallow water gateway $(=300 \mathrm{~m})$ \\
\hline $97-81$ & Cenomanian-Campanian & Benue volcanics, $2^{\text {nd }}$ phase \\
\hline 95 & Cenomanian & Trans-Saharan seaway \\
\hline 90 & Turonian & Deep water gateway \\
\hline $68-49$ & Maastrichtian-Ypresian & Benue volcanics, $3^{\text {rd }}$ phase \\
\hline $70-$ present & Maastrichtian-Present & Cameroon Line volcanics \\
\hline
\end{tabular}

tinents, they have a separate geological history. The interaction of faulting, volcanism, thermal uplift, and sediment loading with sea level can lead to variable subaerial connections between continents, as it has between North and South America.

In either the Africa-first or the pan-Gondwana hypotheses, the last points of connections between the now existing continents are important in biogeography because those are the harbors from which continental-size Noah's Arks depart, or over which dispersals must last take place. Because these last points of contact are tectonically active areas at spreading centers associated with faulting and igneous activity at sea level, these are places where subaerial connections between a continent and off-shelf islands, with or without water gaps - that is, landspans - might well form. The continental connections involved in the Africa-first hypothesis are South America-Africa, South America-Antarctica, AntarcticaAustralia, and Australia-India plus Madagascar. The Equatorial Atlantic Gateway between South America and Africa is most critical in evaluating the Pan-Gondwana model. The point of connection of Australia-India plus Madagascar through the Kerguelen Plateau, which is now mostly submerged but previously was an emergent large igneous province, is equally important for the Africa-first hypothesis (reviewed by Krause et al. 2006).

The events leading to the formation of the Equatorial Atlantic Gateway are summarized in Table II and in less detail in Figure 2. At the paleolatitude of Iembe,
Angola $\left(23^{\circ} \mathrm{S}\right)$, seafloor was present at 128 Ma but marine fossils in the Sergipe Basin, the first evidence of oceanic conditions at the presumptive Equatorial Atlantic Gateway $\left(10^{\circ} \mathrm{S}\right)$ occurs between 115 and $112 \mathrm{Ma}$. By $90 \mathrm{Ma}$ the Equatorial Atlantic Gateway was a deep passage (Handoh et al. 1999). Between $100 \mathrm{Ma}$ and $90 \mathrm{Ma}$ the Trans-Saharan Seaway, from Nigeria to the Mediterranean, occurred (Giresse 2005). Throughout the time the South Atlantic was opening and the Equatorial Atlantic Gateway was forming, the volcanic St. Helena Hotspot and related Cameroon Line have been active, creating both volcanic relief and thermal buoyancy, with subsequent thermal subsidence (Sahagian 1988, Coulon et al. 1996, Adam et al. 2007). The Cenomanian and Turonian interval was a time of high sea level, with high stands approaching 100 meters above present sea level (Müller et al. 2008). Sediments at the Turonian locality of Iembe, Angola, are indicative of a coastal environment yet are found near today's sea level, indicating a net subsidence of 100 meters in the last $90 \mathrm{Ma}$. Throughout the interval of time in which the Equatorial Atlantic Gateway was forming, from 115 to $90 \mathrm{Ma}$, the African and South American continents were subject to marine flooding, but at the same time, volcanic activity and rifting produced physiographic relief, thermal uplift, and sag. The volcanoes formed along the St. Helena Hotspot trace, the Cameroon Line, and the Benoue Trough include both off-shelf and continental. Thermal uplift accompanying rifting and volcanism dur- 
ing the Cretaceous raised land surface elevations, which concomitantly reduced sea depth in this region in a time of global high sea stands. Shifting paleogeography both on and off shore throughout this 15 million-year time interval may well have been conducive to the development of a dynamic set of landspans acting as sequential independent biogeographic states through time that would together have acted as a filter in dispersal but not prevented it. Thus, in our opinion faunal exchange between South America and Africa was at least possible up until the deepwater connection of the Equatorial Atlantic Gateway, which was in place by $90 \mathrm{Ma}$. Therefore, we cannot falsify the Pan-Gondwana hypothesis. However, we do not consider that this conclusion eliminates all relevance of the Africa-First hypothesis because that biogeographic avenue is independent of the connection between Africa and South America. In addition to the Equatorial Atlantic Gateway, landspans may have played a role in dispersal across the Kergulen Plateau and between Africa and India.

We have focused in this paper on the application a new technique to the evaluation of historical biogeographic principles first espoused by Malcolm C. McKenna. One aspect of our approach in this paper has been to apply broad paleoclimatic principles to the tracing of localities through latitudinal climate zones. Our second contribution is more speculative, but provides examples of how landspans may have played a significant role in Gondwana dinosaur historical biogeography. Those speculative hypotheses are testable in two ways. First, geophysical investigation of potential landspans should be undertaken to determine the physical realities of hypothesized connections. Second, only the fauna will reliably represent the patterns of dispersal, vicariance, and distribution that are the subject of biogeography. That is also where the most promise lies for paleontologists - in the discovery of more and better fossils.

\section{ACKNOWLEDGMENTS}

We are grateful to the organizers of the Gondwana Dinosaur Symposium, Yukimitsu Tomida and Alexander Kellner, for extending to us an invitation to submit this paper. Conversations with our colleagues on Projecto PaleoAngola helped us to develop our ideas. We thank Timothy Scott Myers for his discussions with us about marine deposits in the Congo Basin. LLJ is especially pleased with the opportunity to consider the ideas about historical biogeography presented here because, as a graduate student in the early 1970's, he participated in a semester-long seminar on the subject led by George Gaylord Simpson and Everett H. Lindsay (both of whom were also mentors to the Gondwana Dinosaur Symposium organizer Yukimitsu Tomida). This was followed by an association and friendship with Edwin Harris Colbert at the Museum of Northern Arizona while he was studying Gondwana vertebrates from Antarctica, and with MNA trustee Malcolm McKenna, both of whom generously shared their thoughts about historical biogeography.

\section{RESUMO}

As massas de terra do Gondwana serviram como Arcas de Noé biogeográficas de grande escala e Navios Funerários Vikings encalhados, conforme definido por McKenna. As trajetórias latitudinais de áreas selecionadas de dinossauros do Gondwana foram traçadas ao longo do tempo a fim de avaliar seu movimento através de zonas climáticas relativas àquelas nas quais elas foram originalmente formadas. A dispersão da fauna durante a quebra do Gondwana pode ter sido facilitada pela presença de ilhas oceânicas formando extensões de terra (sensu Iturralde-Vinent e MacPhee) na entrada do Atlântico Equatorial e em outros lugares.

Palavras-chave: biogeografia, dinossauro, Gondwana, latitude.

\section{REFERENCES}

ADAM C, VidAL V AND ESCARTín J. 2007. 80-Myr history of buoyancy and volcanic fluxes along the trails of the Walvis and St. Helena hotspots (South Atlantic). Earth Planet Sci Lett 261: 432-442.

Bengtson P And Koutsoukos EAM. 1992. Ammonite and foraminiferal dating of the first marine connection between the central and south Atlantic. In: CURnELlE $\mathrm{R}$ (Ed), Géologie africaine: Colloque de stratigraphie et du paléogéographie des bassins sédimentaires Ouest-Africains. Recueil de Communications, 6-8 May, 1991, Libreville, Gabon. Bull Cent Rech Explor-Prod Elf-Aquitaine Mémoire 13: 403.

Bice KL, Birgel D, Meyers PA, DAhl KA, Hinrichs K-U AND NORRIS RD. 2006. A multiple proxy and 
model study of Cretaceous upper ocean temperatures and atmospheric $\mathrm{CO}_{2}$ concentrations. Paleoceanography 21: PA2002, doi:10.1029/2005PA001203, 2006.

Bice KL, Huber BT AND Norris RD. 2003. Extreme polar warmth during the Cretaceous greenhouse? Paradox of Turonian $\delta^{18} \mathrm{O}$ record at Deep Ocean Drilling Project Site 511. Paleoceanography 18: 1031, doi:10.1029/2002PA000848, 2003.

BICE KL AND NorRis RD. 2002. Possible atmospheric $\mathrm{CO}_{2}$ extremes of the middle Cretaceous (late Albian-Turonian) Paleoceanography 17: 1070, doi:10.1029/2002PA000778, 2002.

Bocharova NY AND Scotese CR. 1993. Revised global apparent polar wander paths and global mean poles. PALEOMAP Project Progress Report 56-1293: 1-20.

Bowen B, Meylan AB and Avise JC. 1989. An odyssey of the green sea turtle: Ascension Island revisited. Proc Natl Acad Sci 86: 573-576.

BRIGgS JC. 2003. The biogeographic and tectonic history of India. J Biogeogr 30: 381-388.

BRownFIELD ME AND CHARPENTIER RR. 2006. Geology and total petroleum systems of the West-Central Coastal Province (7203), West Africa. US Geol Surv Bull 2207-B: $1-52$.

Cande SC, Lebrecque JL, Larson RL, Pitman III WC, Golovchemko X And HaXby WF. 1989. Magnetic lineations of the world's ocean basins. Am Ass Petrol Geol Map, 1:27,400,000: 1 sheet, 13 p.

CARr A AND Coleman PJ. 1974. Seafloor spreading theory and the odyssey of the green turtle. Nature 249: 128-130.

Channel Jet, Erba E, Nakanishi M And TAmaki K. 1995. Late Jurassic-Early Cretaeous time scales and oceanic magnetic block anomaly models. In: BERGGREN WA, Kent DV, Aubry M-P And Hardenbol J (Eds), Geochronology, Time Scales and Global Stratigraphic Correlations. SEPM Special Publication, p. 51-63.

Chatterjee S And Scotese C. 2009. The wandering Indian plate and its changing biogeography during the Late Cretaceous-Early Tertiary period. Platinum Jubilee, Indian Statistical Institute, p. 60-91.

Chatterjee S And Scotese CR. 1999. The breakup of Gondwana and the evolution and biogeography of the Indian Plate. Proc Indian Natn Sci Acad 65: 397-425.

Christie DM, Duncan RA, MCNiRney AR, Richards MA, White WM, Harpp KS AND Fox CG. 1992. Drowned islands downstream from the Galapagos hotspot imply extended speciation times. Nature 355: 246-248.
Coulon C, Vidal P, Dupuy C, Baudin P, Popoff M, Maluski H And Hermitte D. 1996. The Mesozoic to Early Cenozoic magmatism of the Benue Trough (Nigeria); geochemical evidence for the involvement of the $\mathrm{St}$ Helena Plume. J Petrol 37: 1341-1358.

Diaz HF AND BRadley RS (EDS). 2004. The Hadley Circulation: Present, past and future. Kluwer Academic Publishers, Boston.

FRICKE H AND HISSMAN K. 1990. The natural habitat of coelacanths. Nature 346: 323-324.

GiResse P. 2005. Mesozoic-Cenozoic history of the Congo Basin. J Afr Earth Sci 43: 301-315.

Gradstein F, OgG J And Smith A. 2004. A geologic time scale 2004. Cambridge University Press. Cambridge, UK.

GREHAN J. 2001. Biogeography and evolution of the Galapagos: Integration of the biological and geological evidence. Biol J Linn Soc 74: 267-287.

Grímsson F, DENK T AND SÍMONARSOn LA. 2007. Middle Miocene floras of Iceland - the early colonization of an island? Rev Palaeobot Palynol 144: 181-219.

Handoh IC, Bigg GR, Jones EJW and Inoue M. 1999. An ocean modeling study of the Cenomanian Atlantic: Equatorial paleo-upwelling, organic-rich sediments and the consequences for a connection between the protoNorth and South Atlantic. Geophys Res Lett 26: 223-226.

HaQ BU, Hardenbol J AND VAIL PR. 1987. Chronology of fluctuating sea levels since the Triassic (250 mya to present). Science 235: 1156-1167.

Haq BU, Hardenbol J And Vail PR. 1988. Mesozoic and Cenozoic chronostratigraphy and cycles of sea-level change. Sea level changes: An integrated approach. Spec Publ Soc Econ Paleont Min 42: 71-108.

Hartley AJ, Chong G, Houston J and Mather AE. 2005. 150 million years of climatic stability: Evidence from the Atacama Desert, northern Chile. J Geol Soc London 162: 421-424.

Haywood AM, Valdes PJ And Sellwood BJ. 2000. Global scale paleoclimate reconstruction of the middle Pliocene climate using the UKMO GCM: Initial results. Glob Planet Change 25: 239-256.

He H, PAN Y, TAuXe L, QIN H And Zhu R. 2008. Toward age determination of the M0r (Barremian-Aptian boundary) of the Early Cretaceous. Phys Earth Planet Int 169: 41-48.

ItUrRalde-Vinent MA And MacPheE RDE. 1999. Paleogeography of the Caribbean region: Implications for Cenozoic biogeography. Bull Amer Mus Nat Hist 238: $1-95$. 
Jacobs Ll, Mateus O, Polcyn MJ, Schulp AS, AnTUNes MT, Morais ML And TaVares T DA S. 2006. The occurrence and geological setting of Cretaceous dinosaurs, mosasaurs, plesiosaurs, and turtles from Angola. J Paleont Soc Korea 22: 91-110.

Jacobs Ll, Mateus O, Polcyn MJ, Schulp AS, Scotese CR, Goswami A, Ferguson KM, Robbins JA, VineyARD DP AND Neto AB. 2009. Cretaceous paleogeography, paleoclimatology, and amniote biogeography of the low and mid-latitude South Atlantic Ocean. Bull Geol Soc France 180: 239-247.

Jacobs Ll, Polcyn MJ, TAYlor LH ANd FERGUSON K. 2005. Sea-surface temperatures and palaeoenvironments of dolichosaurs and early mosasaurs. Neth J Geosci 84 : 269-281.

Koutsoukos EAM. 1992. Late Aptian to Maastrichtian foraminiferal biogeography of the Sergipe Basin, Brazil. Palaeogeogr Palaeoclimat Palaeoec 92: 295-324.

Koutsoukos EAM, Mello MR, de Azambua Filho NC, Hart MB And MaXwell JR. 1991. The upper Aptian-Albian succession of the Sergipe Basin, Brazil: An integrated paleoenvironmental assessment. Bull Am Ass Petrol Geol 75: 475-498.

Krause DW, O'CONNOR PM, CURry Rogers K, SAMPSON SD, BUCKLEY GA AND ROGERS RR. 2006. Late Cretaceus terrestrial vertebrates from Ma dagascar: Implications for Latin American biogeography. Ann Mo Bot Gdn 93: 178-208.

MAISEy JG. 2000. Continental breakup and the distribution of fishes of western Gondwana during the Early Cretaceous. Cret Res 21: 281-314.

Marton LG, TARi GC And Lehmenn CT. 2000. Evolution of the Angolan passive margin, West Africa, with emphasis on post-salt structural styles. In: MOHRIAK W And Talwani M (Eds), Atlantic Rifts and Continental Margins. American Geophysical Union. Washington D.C., p. 129-151.

Mateus O, Jacobs Ll, Schulp AS, Polcyn MJ, Tavares TS, Neto AB, Morais ML and Antunes MT. 2011. Angolatitan adamastor, a new sauropod dinosaur and the first record from Angola. An Acad Bras Cienc 83: 221-233.

Matthew WD. 1915. Climate and evolution. Ann NY Acad Sci 24: 171-318.

Matthew WD. 1939. Climate and evolution. Second edition, revised and enlarged. Spec Publ NY Acad Sci 1 (i-xii): 1-223.
MCKEnNA MC. 1973. Sweepstakes, filters, corridors, Noah's Arks, and Beached Viking Funeral Ships in palaeogeography. In: TARLING DH AND RUNCORN SK (Eds), Implications of Continental Drift to the Earth Sciences. Academic Press, New York, p. 295-308.

MCKennA MC. 1983. Holarctic landmass rearrangement, cosmic events, and Cenozoic terrestrial organisms. Ann Mo Bot Gdn 70: 459-489.

Müller RD, Sdrolias M, Gaina C, Steinberger B AND HEInE C. 2008. Long-term sea-level fluctuations driven by ocean basin dynamics. Science 319: 1357-1362

O'CONNOR JM AND DUNCAN RA. 1990. Evolution of the Walvis Ridge - Rio Grande Rise hot spot system. Implications for African and South American plate motions over plumes. J Geophys Res B11: 17475-17502.

O'Connor JM And Le RoeX AP. 1992. South Atlantic hot spot-plume systems: 1. Distribution of volcanism in time and space. Earth Planet Sci Lett 171: 575-589.

O'CONNOR JM, STOFFERS P, VAN DEN BOGAARD P AND MCWILliams M. 1999. First seamount evidence for significantly slower African Plate motion since 19 to $30 \mathrm{Ma}$. Earth Planet Sci Lett 171: 575-589.

Polcyn MJ, TCHERnOV E AND JACOBS LL. 1999. The Cretaceous biogeography of the eastern Mediterranean with a description of a new basal mosasauroid from 'Ein Yabrud, Israel. Natn Sci Mus Tokyo Monogr 15: 259290.

Renne PR, Glen JM, Milner SC And Duncan AR. 1996. Age of the Etendeka flood volcanism and associated intrusions in southwestern Africa. Geology 24: 659662.

Rich TH AND ViCKERS-RICH P. 2000. Dinosaurs of darkness. Indiana University Press.

SACHS JP, SACHSE D, SMitTENBERG RH, ZANG ZH, BATTISTI DS AND GolubiC S. 2009. Southward movement of the Pacific intertropical convergence zone AD 14001850. Nat Geosci 2: 519-525.

SAHAGIAN D. 1988. Epeirogenic motions of Africa as inferred from Cretaceous shoreline deposits. Tectonics 7: $125-138$.

SAmpson SD, WitMer LM, Forster CA, Krause DW, O’CONnOR PM, Dodson P AND RavoAvy F. 1998. Predatory dinosaur remains from Madagascar: Implications for the Cretaceous biogeography of Gondwana. Science 280: 1048-1051.

SCOTESE CR. 2004. Cenozoic and Mesozoic paleogeography: Changing terrestrial biogeographic pathways. In: Lomolino MV And Heaney LR (Eds), Frontiers of 
Biogeography: New Directions in the Geography of Nature. Sinauer Associates, Inc. Publishers, Sunderland, Massachusetts, p. 9-26.

SCOTESE CR. 2008. The PALEOMAP Project paleoatlas for ArcGIS. Volume 2, Cretaceous paleogeographic and plate tectonic reconstructions. PALEOMAP Project, Arlington, Texas.

Scotese CR, Boucot AJ ANd McKerrow WS. 1999. Gondwanan palaeogeography and palaeoclimatology. J Afr Earth Sci 28: 99-114.

Sellwood BW ANd VAldes PJ. 2006. Mesozoic climates: General circulation models and the rock record. Sedimentary Geol 190: 269-287.

Sereno PC, Wilson JA And CONRAd JL. 2004. New dinosaurs link southern landmasses in the mid-Cretaceous. Proc R Soc London B271: 1325-1330.

SIMPSON GG. 1940. Mammals and land bridges. J Wash Acad Sci 30: 137-163.

SIMPSON GG. 1943. Mammals and the nature of continents. Am J Sci 241: 1-31.

SIMPSON GG. 1946. Tertiary land bridges. Trans NY Acad Sci Ser II 8: 255-258.

SIMPSON GG. 1947a. Holarctic mammalian faunas and continental relationships during the Cenozoic. Bull Geol Soc Am 58: 613-688.

SIMPSON GG. 1947b. Evolution, interchange, and resemblance of the North American and Eurasian Cenozoic mammalian faunas. Evolution 1: 218-220.
SIMPSON GG. 1952. Probabilities of dispersal in geologic time. In: MAYR E (Ed), The problem of land connections across the South Atlantic, with special reference to the Cenozoic. Bull Am Mus Nat Hist 99: 163-176.

SIMPSON GG. 1953. Evolution and geography. Condon Lectures, Oregon State System of Higher Education, p. 1-64.

TAQUET P. 1976. Géologie et paleontology du gisement de Gadoufaoua (Aptian du Niger). Cah Paleont Centre Natn Rech Scient, Paris, 191 p.

Torsvik TH, Rousse S, LABAILs C AND SMETHHuRst MA. 2009. A new scheme for the opening of the South Atlantic Ocean and the dissection of an Aptian salt basin. Geophys J Int 177: 1315-1333.

Valença LMM, Neumann VH and Mabesoone JM. 2003. An overview on Callovian-Cenomanian intracratonic basins of the opening of the South Atlantic. Geologica Acta 1: 261-275.

Weishampel DB, Dodson P AND Osmólska H. 2004. The Dinosauria. University of California Press.

Ziegler AM, Barrett SF And Scotese CR. 1981. Palaeoclimate, sedimentation and continental accretion. Phil Trans R Soc London A 301: 253-264.

Ziegler AM, Eshel G, ReEs PM, Rothfus TA, RowLEY DB AND Sunderlin D. 2003. Tracing the tropics across land and sea: Permian to present. Lethaia 36: $227-$ 254. 